\title{
3 産業界の動向
}

\section{Industrial Trend}

\author{
by NAKANISHI Yasumasa*
}

キーワード : 鉱工業生産, 活動指数, 業種別動向, 市 場動向, 旧口イド統計

経済産業省がまとめた 2010 年の産業活動分析によると， 鉱工業生産指数は前年比 $15.9 \%$ と 3 年ぶりの上昇となっ た。 4 半期毎でも，1〜3月は前年同期比 $27.5 \%$ 増， 4 〜 6 月は同 $21.0 \%$ 増， $7 \sim 9$ 月は同 $13.5 \%$ 増， 10〜 12 月 は同 $4.9 \%$ 増となっている。これらの上昇は 2009 年がリー マンショックの影響により減産となった反動の側面が強 く，また，エコカー補助金や省エネ家電エコポイントな どの政策的な経済効果が後押しする形で普通自動車や電 子部品（半導体製造装置）などの生産増が大きく寄与し た。一方で，急激な円高によって輸出が鈍化し景気回復 のスピードを弱めている。さらに，2011年 3 月11日発生 の東日本大震災によって，今後の生産活動が大きな影響 を受けることは必至である。

2010年の主な業種別動向は次の通りである.

\section{【鉄 鋼 】}

粗鋼生産量は， 1 億 960 万トン，前年比 $25.2 \%$ と 3 年 ぶりの増加となり， 2 年ぶりに 1 億トン台を回復した. 鉄鋼業の生産は, 前年比 $29.4 \%$ と 3 年ぶりの上昇となっ た。これは，熱間圧延鋼材の生産が前年比 $25.4 \%$ と 3 年 ぶりに上昇となったこと，冷間仕上鋼材の生産が同 $39.8 \%$ と 3 年ぶりの上昇となったことによる．熱間圧延 鋼材では, 輸出向けおよび自動車向けなどの増加から, 特殊鋼熱間圧延鋼材が前年比 $54.4 \%$ と 2 年ぶりに増加, 普通鋼鋼帯が同 $33.5 \%$ と 3 年ぶりに増加するなど，全て の品目が増加した。冷間仕上鋼材では，自動車向けの増 加などから，普通鋼冷延広幅帯鋼が同 $35.7 \%$ ，特殊鋼冷 間仕上鋼材が同 $50.6 \%$ とともに 3 年ぶりに増加するなど, ほとんどの品目が増加した。

\section{【非鉄金属】}

非鉄金属工業の生産は，非鉄金属鋳物，伸銅・アルミ 二ム圧延製品，非鉄金属地金，電線・ケーブルの全ての 業種が増加したことにより，前年比 $16.9 \%$ と 3 年ぶりの 上昇となった，例えば，伸銅・アルミニウム圧延製品の 生産では，前年比 $22.7 \%$ と 4 年ぶりの上昇となった。こ れは，伸銅製品がアジア向け輸出の増加に加え，エアコ ン向け，コネクタ向けの増加から同 $32.5 \%$ と 4 年ぶりの 増加, アルミニウム板製品が自動車部品向け, 舶用向け などの増加から同 $20.5 \%$ と 3 年ぶりに増加するなど, 全 ての品目が増加したことによる。

\section{【金属製品工業】}

金属製品工業の生産は，超硬チップ，粉末や金属機械 材料などが増加したことにより前年比 $6.7 \%$ と10年ぶりの
上昇となった。しかし，建設用金属製品の生産は減少し ており前年比 $\boldsymbol{\Delta} 16.5 \%$ と 2 年連続の低下となった。これ は, 橋梁が2000トン未満物件, 2000トン以上物件ともに 減少したことにより同 $\mathbf{\Delta} 26.3 \%$ ，鉄骨が事務所向けなど の減少により同 $\mathbf{\Delta} 5.3 \%$ とともに 2 年連続で減少, 軽量鉄 骨が同 $\mathbf{\Delta} 0.5 \%$ と 4 年連続で減少したことによる.

\section{【一般機械工業 】}

一般機械工業の生産は，前年比 $38.5 \%$ と 3 年ぶりの上 昇となった。これは, 化学機械などが減少したものの, 半導体・フラットパネル製造装置, 風水力機械・油圧機 器などが増加したことによる。半導体・フラットパネル 製造装置の生産は前年比 $82.9 \%$ と 4 年ぶりの上昇, 風水 力機械・油圧機器の生産は同 $53.2 \%$ と 3 年ぶりの上昇, 土木建設機械の生産は同 $84.1 \%$ と 3 年ぶりの上昇, 産業 用ロボットの生産は同 $144.5 \%$ と 3 年ぶりの上昇となっ た。一方で，化学機械の生産は，前年比 $\mathbf{\Delta} 21.2 \%$ と 7 年 ぶりの低下となり, 運搬機械の生産は, 同 $\mathbf{\Delta} 8.0 \%$ と 3 年 連続の低下となった。

\section{【輸送機械工業 】}

輸送機械工業の生産は, 前年比 $26.4 \%$ と 3 年ぶりの上 昇となった。これは, 鉄道車両が減少したものの, 乗用 車, 自動車部品, トラックなどが増加したことによる。 乗用車の生産は, エコカー補助金・減税による国内需要 の底上げ, 米国, 欧州向けの回復, 新興国向けが増加し たことにより前年比 $27.5 \%$ と 3 年ぶりの上昇となった。 自動車部品の生産は, ASEAN, 米国, 東アジア向けに加 え, 国内向けが増加したことにより $30.4 \%$ と 3 年ぶりの 上昇となった。

\section{【造 船】}

World Shipbuilding Statistics（旧ロイド統計）に基づ く日本造船工業会の資料によれば，2010年新造船の受注 量および竣工量は次のようである.

世界の新造船受注量は，2,526 隻 77,806千総トンであり 前年比 $131.6 \%$ の増加となった. 各国別では, 日本 385 隻 10,594 千総トン（前年比 $24.5 \%$ 増), 韓国 467 隻 27,712 総 千トン（同 $225.2 \%$ 増）, 中国 926 隻 33,460 総千トン（同 $123.9 \%$ 増）であった. すなわち, 受注量の総トンベース 国別シェアは，日本 $13.6 \%$, 韓国 $35.6 \%$, 中国 $43.0 \%$ と なり，2 位韓国と 3 位日本の差が広がった。新造船竣工 量は，3,706 隻 96,012 千総トンであり前年比 $24.6 \%$ の増加 となった。各国別では，日本 577 隻 20,171 千総トン（前 年比 $6.3 \%$ 増), 韓国 524 隻 31,546 総千トン（前年比 $9.3 \%$ 増), 中国 1,402 隻 36,239 総千トン（前年比 65.0 増）であ った。竣工量の総トンベース国別シェアは，日本 $21 \%$, 韓国 32.9\%, 中国 37.7\% となり，中国が韓国を抜いて 1 位となった。 